\title{
AMTSAL OF THE QUR'AN IN DAKWAH: ACTUALIZATION OF QUALITY HUMANS BASED ON SURAH IBRAHIM: 24-25
}

\section{AMTSAL AL-QUR'AN DALAMDAKWAH: AKTUALISASI MANUSIA BERKUALITAS BERDASARKAN SURAH IBRAHIM: 24-25}

\author{
P-ISSN: 2085-5818 | E-ISSN: 2686-2107 \\ Url Jurnal: https://uia.e-journal.id/Al-Risalah/article/1450 \\ DOI : 10.34005/alrisalah.v12i2.1450
}

Naskah Dikirim: 04-07-2021

Naskah Direview: 06-07-2021

Naskah Diterbitkan: 10-072021

\section{KUSWATI}

\section{Universitas Gunadarma}

\section{kuswati564@gmail.com}

\begin{abstract}
One of the language styles conveyed by Allah through the Qur'an is in the form of parables (amtsal al-Qur'an). This form becomes interesting as it presents something abstract into a real form, by analogizing objects or situations that have similarities. No doubt that the language style with this example gives a beautiful impression and makes an impression. With the inseparability of three things; dakwah, communication, and language, the delivery of information packaged in the form of an example becomes something important and has many benefits for mad'u. Allah exemplifies quality humans in Surah Ibrahim/14: 24-25 with a good tree where the tree is one of Allah's creations that is close to humans. Quality humans are good quality humans, who are described as trees with strong roots, branches soaring to the sky and can be harvested at any time. The actualization of this example illustrates the condition of quality human beings who have a solid creed, because this creed is the basis for implementing God's rules. Always do good and benefit others wherever and whenever we are.
\end{abstract}

Keywords:amtsal al-Qur'an, actualization, dakwah, human, quality.

Abstrak:Salah satu gaya bahasa yang di sampaikan Allah melalui al-Qur'an adalah dengan bentuk perumpamaan (amtsal al-Qur'an). Bentuk ini menjadi menarik karena menghadirkan sesuatu yang abstrak menjadi bentuk nyata, dengan cara menganalogikan benda atau keadaan yang memiliki keserupaan. Dan tidak dipungkiri gaya bahasa dengan permisalan ini memberi kesan yang indah dan membekas. Ada tiga hal yang tidak bisa dipisahkan dalam ruh Islam yakni: dakwah, komunikasi dan bahasa,maka penyampaian informasi yang dikemas dalam bentuk permisalan menjadi sesuatu yang penting dan memiliki banyak manfaat bagi mad'u. Allah mempermisalkan manusia berkualitas dalam surah Ibrahim/14: 24-25 dengan sebuah pohon yang berkualitas baik di mana pohon adalah salah satu ciptaan Allah yang dekat dengan manusia.Manusia berkualitas adalah manusia yang bermutu baik, yang digambarkan sebagai pohon yang kuat akarnya, cabangnya menjulang ke langit dan dapat dipanen setiap saat. Aktualisasi permisalan ini menggambarkan kondisi manusia berkualitas yakni memiliki akidah yang kokoh, karena akidah inilah yang menjadi dasar melaksanakan aturan-aturan Allah. Selalu berbuat kebajikan dan bermanfaat bagi orang lain di manapun dan kapanpun berada.

Kata kunci: amtsal al-Qur’an, aktualisasi, dakwah, manusia, kualitas.

Kuswati | Amtsal Al-Qur'an Dalam Dakwah : Aktualisasi Manusia Berkualitas Berdasarkan Surah Ibrahim : 24-25 


\section{A. PENDAHULUAN}

Al-Qur'an adalah firman Allah yang diturunkan kepada nabi Muhammad melalui malaikat Jibril yangberfungsi sebagai petunjuk bagi manusia. AyatayatNya mengandung ajaran,baik yang bersifat global maupun rinci. Secara garis besar, ruang lingkup kandungan al-Qur'an mencakup akidah, syariah dan ahlak. Ketiga hal inilah yang mengarahkan hidup manusia untuk mencapai kebahagiaan dunia dan akhirat. Maka dapat dikatakan bahwa al-Qur'an adalah kurikulum terbaik dan terhebat bagikehidupan manusia.

Sebagai sebuah kitab suci yang berperan menyampaikan informasi kepada manusia, maka al-Qur'an memiliki cara yang berbeda-beda dalam menyampaikan pesannya agar pesan tersebut dapat dipahami dan diamalkan. Berbagai macam cara yang digunakan al-Qur'an dalam menyampaikan pesan, di antaranya: berbentuk pernyataan langsung yang mengarah pada perintah atau larangan, bentuk pertanyaan, pemaparan kisah-kisah yang mengandung hikmah, serta yang tidak kalah menariknya adalah bentuk permisalan sesuatu yang abstrak dengan sesuatu yang kongkrit. Adanya permisalan-permisalan di dalam al-Qur'an, menarik perhatian para ulama sehingga di antara mereka ada yang memfokuskan diri untuk mengkajinya.Pada akhirmya,ilmu ini menjadi bagian tersendiri dalam disiplin ulumum al-Qur'an yang disebut ilmu amsal alQur'an.

Pondasi seorang muslim dengan ketauhidan yang kuat, akan mejadikannya mudah dalam menjalankan syari'at dan memiliki ahlak yang baik dimanapun berada. Kondisi ini Allah perumpamakan sebagai pohon yang baik yakni memiliki karakter: kuat akarnya, cabangnya menjulang ke langit dan menghasilkan buah. Karakter inilah yang mencirikan manusia berkualitas.

\section{B. METODOLOGI}

Metode yang digunakan dalam kajian ini adalah metode kajian pustaka dan analisa referensi-referensi ilmiah terkaitamtsal al-Qur'an dalam dakwah: aktualisasi manusia berkualitas dalam surah Ibrahim/14: 24-25). Hasil dari kajian ini adalah penggunaan gaya bahasa permisalan dalam berdakwah sangatlah penting agar informasi yang disampaikan lebih membekas dan menarik. Permisalan yang disampaikan Allah dalam ayat tersebut adalah kondisi manusia berkualitas bagaikan pohon yang kuat akarnya, cabangnya menjulang ke langit dan dapat dipanen setiap saat. Maka aktualisasi dalam kehidupan adalah manusia yang akidahnya kuat dan selalu beramal sholeh dengan akidah yang kuat manusia akan mampu dan mudah menjalankan aturan-aturan Allah.

\section{PEMBAHASAN}

\section{Amtsal al-Qur'ansebagai retorikadakwah}

\section{a. Pengertian amtsal al-Qur'an}


Amtsal adalah bentuk jama' dari masal. Kata masal,mis/dan masil adalah sama dengan syabah, syibh, baik lafaz maupun maknanya.Imam alSuyuthi dalam kitab al-Itqon fi ulum al-Qur'an mengutip sebuah hadis, ${ }^{1}$

$$
\begin{aligned}
& \text { وأخرجه البيهتي عن أبي هريرة: قال رسول الله صلى الله عليه وسلم: إن القرآن نزل }
\end{aligned}
$$

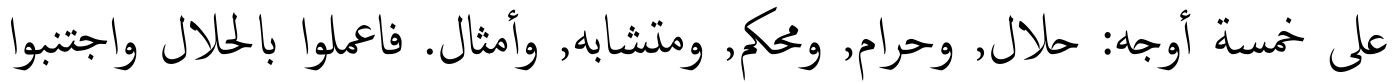

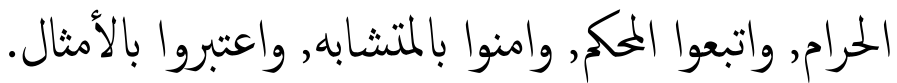

"dikeluarkan dari Imam Baihaqi dari Abu Hurairah: Rasulullah SAW berkata: Sesungguhnya al-Qur'an diturunkan dalam lima bentuk: halal, haram, muhkam ${ }^{2}$, mutasyabih ${ }^{3}$ dan amtsal. Maka kerjakanlah yang halal, jauhi yang haram, ikuti yang muhkam, yakini yang mutasyabih, dan ambillah pelajaran yang (berbentuk) amtsal."

Berkata Syeik 'Izzu al-Din dalam kitab yang sama, sesungguhnya Allah membuat permisalan adalah sebagai peringatan, nasehat yang mengandung berbagai macam bentuk. Baik berbentuk perintah, atau penegasan suatu pekerjaan, pujian, celaan dan sebagainya, yang semua itu menunjukkan keberadaan suatu hukum. ${ }^{4}$

Dengan demikian, amtsal merupakan salahsatu cara yang digunakan al-Qur'an untuk menyampaikan pesan kepada pembacanya sehinnga mampu mengambil hikmah. Karena dengan menghadirkan sesuatu yang kongkit untuk suatu pesan akan lebih membekas dan gampang diingat. IImu amtsal merupakan salah datu pembahasan dalam ulum alQur'an,sehingga imam Syafi'i menganggap ilmu ini merupakan persyaratan yang harus dikuasai oleh seorang mujtahid.

Permisalan yang terdapat di dalam al-Qur'an berbeda-beda redaksinya. Amtsal al-Qur'an ada tiga macam: ${ }^{5}$

1) Amtsal Musarrahah, ialah yang di dalamnya dijelaskan dengan lafadz matsal atau sesuatu yang menunjukkan tasybih. Amtsalseperti ini banyak ditemukan di dalam al-Qur'an, contohnya surah al-Baqarah/2: 17-18

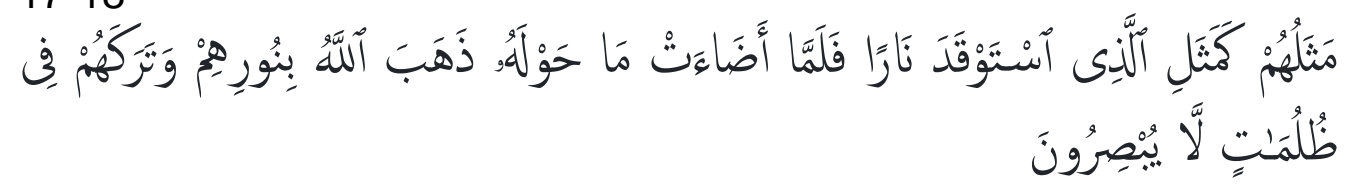

"Perumpamaan mereka adalah seperti orang yang menyalakan api, Maka setelah api itu menerangi sekelilingnya Allah hilangkan cahaya (yang menyinari) mereka, dan membiarkan mereka dalam kegelapan, tidak dapat melihat."

\footnotetext{
${ }^{1}$ Al-Suyuthi, al-Itqon fi ulum al-Qur'an (Cairo: al-Dar al-'alamiyyah, 2016), h. 589-590

${ }^{2}$ Ayat muhkam adalah ayat-ayat yang mudah diketahui maksudnya tanpa memerlukan keterangan yang lain.

${ }^{3}$ Ayat mutasyabih adalah ayat yang hanya Allah yang mengetahuinya serta memerlukan penjelasan lain.

${ }^{4}$ Al-Suyuthi, al-Itqon fi ulum al-Qur'an, h.590

5 Manna' Khalil al-Qattan, Studi Ilmu-ilmu al-Qur'an. Penerjemah Mudzakir AS (Jakarta: PT Pustaka Lentera Antar Nusa, 2006), h. 404-409
}

Kuswati | Amtsal Al-Qur'an Dalam Dakwah : Aktualisasi Manusia Berkualitas Berdasarkan Surah Ibrahim : 24-25 
2) Amtsal kaminah, ialah yang di dalamnya tidak dijelaskan lafadz tamtsil(permisalan) tetapi ia menunjukkan makna-makna yang indah, menarik dalam kepadatan redaksinya, dan memiliki pengaruh tersendiri bila dipindahkan kepada yang serupa dengannya. Contoh: ayat senada dengan خير الأمور الوسط diantaranya surah al-Isra/17: 29

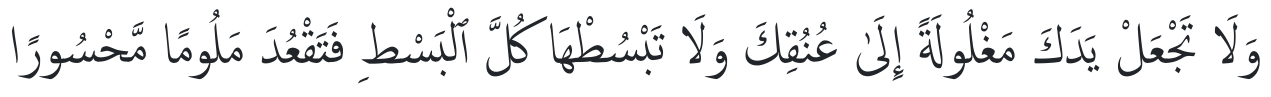

"Dan janganlah kamu jadikan tanganmu terbelenggu pada lehermu dan janganlah kamu terlalu mengulurkannya karena itu kamu menjadi tercela dan menyesal". ${ }^{6}$

3) Amtsal mursalah, ialah kalimat-kalimat bebas yang tidak menggubnakan lafadz tasybih secara jelas, tetapi kalimat tersebut berlaku sebagai matsal. Contoh surah Yusuf/12: 51 , "...Sekarang jelaslah kebenaran itu...."

Amtsal memiliki faedah yang sangat luar biasa dalam memberikan pemahaman kepada orang yang mendengarkannya. Hal ini karena pemahaman yang sifatnya abstrak terkadang butuh waktu dan sulit dipahami. Akan tetapi dengan menghadirkan permisalan dengan benda yang konkrit dan dekat dengan kehidupan kita karena memiliki kesamaan karakter yang dimaksud. Maka hal itu dapat memudahkan, mudah dipahami danmembekas. Oleh karena itu fungsi amtsal al-Qur'an adalah sebagai berikut:

1) Menonjolkan sesuatu yang ma'qul (yang hanyanya bisa dijangkau akal, abstrak)dalam bentuk kongkrit yang bisa dirasakanindera manusia, sehingga akal dapat menerimanya. Sebab pengertian abstrak tidak dapat tertanam dalam benak kecuali dituangkan dalam bentuk inderawi yang dekat dengan pemahaman. Misalnya dalam firman Allah mengenai keadaan orang yang menafkahkan hartanya karena riya' tidak akan mendapatkan pahala sedikitpun karena perbuatannya. (QS. 2:24).

2) Menyingkap hakikat-hakikat dan mengemukakan sesuatu yang tidak Nampak seakan-akan sesuatu yang nampak. (QS. 2:275).

3) Mengumpulkan makna yang menarik dan indah dalam uangkapan yang padat, seperti pada amtsal kaminah dan amtsal mursalah.

4) Mendorong orang yang diberi matsal untuk berbuat seperti yang dimisalkan, jika ia adalah sesuatu yang disenangi jiwa. Misalnya firman Allah yang menafkahkan hartanya di jalan Allah, ia akan diberi kebaikan yang banyak. (QS 2:261).

\footnotetext{
${ }^{6}$ Maksudnya: jangan kamu terlalu kikir, dan jangan pula terlalu pemurah.
} 
5) Untuk menjauhkan perbuatan tersebut, jika hal tersebut sesuatu yang dibenci jiwa. Misalnya firman Allah tentang larangan bergunjing. (QS. 49:12).

6) Untuk memuji orang-orang yang diberi masal. (QS. 48:29). ${ }^{7}$

\section{b. Amtsal al-Qur'an sebuahretorika dakwah}

Secara etimologis, kata dakwah berasal dari kata bahasa Arab - lesyang berarti menyeru, memanggil, mengajak, mengundang (Mahmud Yunus, 1973: 127). Kata dakwah secara etimologis terkadang digunakan dalam arti mengajak kepada kebaikan yang pelakunya ialah Allah SWT, para Nabi dan Rasul serta orangorang yang telah beriman dan beramal shaleh. Terkadang pula diartikan mengajak kepada keburukan yang pelakunya adalah syaitan, orang-orang kafir, orang-orang munafik dan sebagainya.Kata dakwah yang mengajak kepada kebaikan antara lain disebutkan dalam surah al-Baqarah/2: 221 sebagai berikut:

"...Dan Allah mengajak ke syurga dan ampunan dengan izinNya, dan Allah menerangkan ayat-ayat-Nya (perintah-perintah-Nya) kepada manusia supaya mereka mengambil pelajaran".

Sedang kata dakwah yang berarti mengajak kepada kejahatan, antara lain disebutkan dalam firman Allah surah Fatir/35: 6

"Sesungguhnya syaitan itu adalah musuh bagimu, maka anggaplah ia musuh(mu), karena sesungguhnya syaitansyaitan itu hanya mengajak golongannya supaya mereka menjadi penghuni neraka yang menyalanyala". ${ }^{8}$

Sedangkan menurut istilah, para ulama' memberikan ta'rif (definisi) yang bermacam-macam antara lain :

1) Syech Ali Mahfudh dalam kitabnya Hidayatul Mursyidin mengatakan dakwah adalah: Mendorong manusia untuk berbuat kebajikan dan mengikuti petunjuk (agama), menyeru merka pada kebaikan dan mencegah mereka dari perbuatan munkar agar mereka memperoleh kebahagiaan dunia akhirat.

2) HSM. Nasaruddin Latif dalam bukunya Teori dan Praktek Dakwah Islamiyah mendefinisikan dakwah Islamiyah sebagai: Setiap aktivitas dengan lisan dan tulisan yang bersifat menyeru, mengajak, memanggil manusia lainnya untuk beriman dan mentaati Allah SWT, sesuai dengan garis-garis akidah dan syariat serta akhlak Islamiyah. ${ }^{9}$

\footnotetext{
${ }^{7}$ Muhammad Chirzin, al-Qur'an dan Ulumul Qur'an (Yogyakarta: PT. Dana Bhakti Prima Yasa, 1998), h. 131-132

8 Muhammad Qadaruddin Abdullah, Pengantar IImu Dakwah (Jakarta: CV. Qiara Media, 2019), h. 2

${ }^{9}$ H. Mohammad Hasan, Metodologi Pengembangan Ilmu dakwah (Surabaya: Pena Salsabila, 2013), h. 9
}

Kuswati | Amtsal Al-Qur'an Dalam Dakwah : Aktualisasi Manusia Berkualitas Berdasarkan Surah Ibrahim : 24-25 
Ada 3 hal yang tidak dapat kita pisahkan dalam konteks menyampaikan informasi dan mengajak orang lain, yaitu dakwah, komunikasi dan bahasa. ${ }^{10} \mathrm{Kegagalan}$ dakwah terkadang berasal dari kegagalan pendakwah penyampaian informasi yang ingin dijelaskan. Dalam hal ini peran bahasa menjadi sangat diperlukan dalam berdakwah, baik bahasa verbal maupun non verbal. Dalam bahasa verbal pemilihan kosa kata yang tepat, penggunaan gaya bahasa perlu sangatlah penting. Tidak dipungkiri dengan diksi yang tepat akanlebih mudah dipahami dan dengan menggukan gaya bahasa sastta yang menarik seperti ungkapan, permisalan, pantun akan mudah membekas dan pengaruh.

Dalam dakwah tidak terlepas dari istilah retorika ${ }^{11}$. Retorika dan dakwah ibarat dua sisi mata uang, mempunyai hubungan yang sangaterat. Retorika dakwah dapat dipahami sebagai seni berbicara di depan orang banyak yang dilakukan dengan pelafalan kata-kata yang baik, tegas, dan jelas. Retorika berasal dari bahasa Yunani "Rhetor" atau dalam bahasa Inggrisnya "orator" yang berarti kemahiran dalam berbicara dihadapan umum. I Gusti Ngurah Oka memberikan definisi retorika sebagai ilmu yang mengajarkan tindak dan usaha untuk persiapan, kerjasama, serta kedamaian ditengah masyarakat". ${ }^{12}$

Style atau gaya bahasa dalam wacana sastra merupakan deskripsi khusus pilihan bahasa seorang pengarang, baik berupa lisan maupun tulisan, mulai dari yang paling luas tentang struktur kalimat hingga pilihan kata yang paling sederhana. Persoalan gaya bahasa meliputi semua bentuk kebahasaan, termasuk pilihan kata secara individual, frasa, klausa, kalimat, ataupun segala sesuatunya yang mencakup sebuah wacana secara keseluruhan, termasuk makna yang tersirat di balik bahasa. Dalam bahasa Arab Gaya Bahasa ${ }^{13}$ disebut "uslub" yang merupakan kajian tentang gaya bahasa yang mencakup aspek leksikall ${ }^{14}$, gramatikal ${ }^{15}$, dan semantik ${ }^{16}$. Stilistika merupakan bagian dari retorika yang bertujuan untuk menciptakan keindahan ungkapan. Dengan stilistika, kegiatan beretorika akan terasa indah dan menarik untuk didengar.(Aminuddin, 1995) 3 Dalam wawasan retorika klasik, style diartikan sebagai teknik serta bentuk gaya bahasa seseorang dalam memaparkan gagasan sesuai dengan ide dan norma yang

\footnotetext{
10 Djamalul Abidin ASS, Komunikasi dan Bahasa Dakwah (Jakarta: Gema Insani Press, 1996), h. 1

${ }^{11}$ Retorika dakwah Islam adalah kepandaian berbicara dalam mengajak orang lain untuk memeluk, mempelajari dan mengamalkan ajaran Islam.

12 Agus Hermawan, Retorika Dakwah (Kudus: al-Nur, 2018), h. 1

13 Gaya Bahasa adalah pemakaian ragam bentuk untuk memperoleh efek-efek tertentu yang membuat suatu karya sastra semakin hidup.

14 Leksikal adalah makna yang bersifat tetap dan tidak terikat dengan makna lainnya (berdiri sendiri). Makna leksikal sering disebut makna yang sesuai dengan kamus. Contoh: Rumah adalah bangunan untuk tempat tinggal.

15 Gramatikal adalah makna yang berubah-ubah sesuai dengan konteks pemakainya. Hal ini terjadi akibat proses-proses gramatikal yang terjadi pada kata tersebut, seperti pengimbuhan, dan pemajemukan.

16 Semantik adalah cabang linguistic yang mempeajari makna/ arti yang terkandung dalam bahasa, kode, atau jenis lain dari representasi.
}

Kuswati | Amtsal Al-Qur'an Dalam Dakwah : Aktualisasi Manusia Berkualitas Berdasarkan Surah Ibrahim : 24-25 
digunakan sebagai ciri khas pribadi pemakainya. Pada masa Renaissance, style diartikan sebagai gaya untuk menyusun dan menggambarkan sesuatu secara tepat dan mendalam hingga dapatmenampilkan keindahan tertentu sesuai dengan impresi dan tujuan pemaparnya. ${ }^{17}$

\section{Definisi Manusia Menurut al-Qur’an}

Pembahasan tentang manusia adalah pembahasan yang sangat luas bagaikan lautan yang tak bertepi, oleh karena itu memahami manusia tergantung dari sisi mana manusia akan dikaji. Dalam buku Wawasan alQur'an, M. Quraish Shihab memulai pembahasan manusia dengan memaparkan beberapa kosa kata "manusia"yang digunakan al-Qur'an.Ada tiga kata yang digunakan al-Qur'an untuk menunjuk manusia:

a. Menggunakan kata yang terdiri dari huruf alif, nun dan sin semacam insan, ins, nas atau unas.

b. Menggunakan kata basyar.

c. Menggunakan kata bani Adam, dan dzurriyat Adam. ${ }^{18}$

Kata insan terambil dari kata uns yang berarti jinak, harmonis dan tampak. Pendapat ini jika ditinjau dari sudut pandang al-Qur'anlebih tepat dari yang berpendapat bahwa ia terambil dari kata nasiya (lupa), atau nasa-yanusu (berguncang). Kata insan, digunakan al-Qur'anuntuk menunjuk kepada manusia dengan seluruh totalitas, jiwa dan raganya. Manusia yang berbeda antara seseorang dengan yang lain, akibat perbedaan fisik, mental dan kecerdasan. ${ }^{19}$

Pada hakekatnya lupa adalah ketidakmampuan mengingat kembali suatu informasi, sehingga tidak bisa memunculkan informasi tersebut baik dengan ucapan maupun perilaku. Kata lupa mengarahkan kita pada meninggalkan sesuatu yang menjadi kewajiban atau yang menjadi tugasnya. Kata insan jika dihubungkan dengan makna lupa, maka sangatlah berhubungan erat tujuan Allah menurunkan risalahNya berupa agama yang di dalamnya mengandung nasehat agar manusia tidak lupa dan keluar dari jalur yang benar.

Kata basyarterambil dari akar kata yang pada mulanya berarti penampakan sesuatu yang baik dan indah. Dari akar kata yang sama lahir kata basyarah yang berarti kulit. Manusia dinamai basyar karena kulitnya tampak jelas, dan berbeda dengan kulit binatang yang lain. Dari sisi lain diamati bahwa banyak ayat-ayat al-Qur'an yang menggunakan kata basyar yang mengisyaratkan bahwa proses kejadian manusia menjadi basyar, melalui tahap-tahap sehingga mencapai tahap kedewasaan. ${ }^{20}$ Sebagaimana dalam surah al-Rum/30: 20,

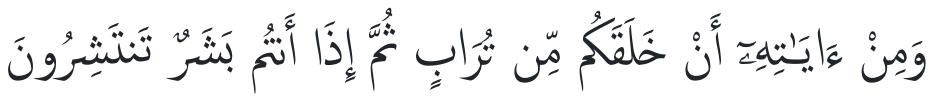

\footnotetext{
17 Yaniah Wardani, "Pemakaian Pribahasa dan Kata Mutiara dalam Retorika Dakwah Para Da'i di Indonesia : Kajian Stalistika dalam Sastra Arab-Indonesia", Buletin al-Turas Vol. XXIV, No.2 (Juli 2018), h. 326

18 M. Quraish Shihab, Wawasan Al-Qur'an (Bandung: PT Mlzan Pustaka, 2007), h. 278

19 lbid. h. 280

${ }^{20} \mathrm{lbid}$. h. 279
}

Kuswati | Amtsal Al-Qur'an Dalam Dakwah : Aktualisasi Manusia Berkualitas Berdasarkan Surah Ibrahim : 24-25 
"Dan di antara tanda-tanda kekuasaan-Nya ialah Dia menciptakan kamu dari tanah, kemudian tiba-tiba kamu (menjadi) manusia yang berkembang biak".

Dari kata basyar ini, dapat dipahami bahwa manusia mengalami proses baik jasmani maupun pemahaman spiritalnya. Kata ini sangatlah tepat dengan konsep hijrah dalam Islam. Di mana seorang muslim dituntun untuk berproses menjadi manusia yang lebih baik dengan meninggalkan keburukan yang dilakukan sebelumnya menuju kebaikan.

Sedangkan pengertian dzurriyat Adamatau bani Adam menunjukkan bahwa manusia adalah keturunan nabi Adam sebagai khalifah pertama yang tunjuk Allah. Penyebutan kata ini juga menggambarkan manusia adalah mahluk yang mulia sebagaimana Allah memuliakan nabi Adam dengan meminta iblis sujud (hormat) padanya.

Dengan mengerucutkan pembahasan manusia melalui kosa kata yang Allah gunakan dalam al-Qur'an, paling tidak kita dapat mengetahui karakter yang dimiliki oleh manusia. Yakni mahluk yang diciptakan Allah dengan segala kelebihan dan kekurangnnya, mahluk yang keberadaannya selalu berproses, dan mahluk yang Allah muliakan dengan amanah khalifah yang dimulai dengan manusia pertama yang diciptakan yaitu nabi Adam.

Sedangkan Zaki Mubarak dalam bukunya Menjadi Cendikiawan Muslim memaparkan karakter manusia sebagai berikut:21

a. Mahluk yang sempurna dan mulia.

Penyematan manusia sebagai mahluk mulia Allah tegaskan dalam surah al-Isra'/17: 70 sebagai berikut,

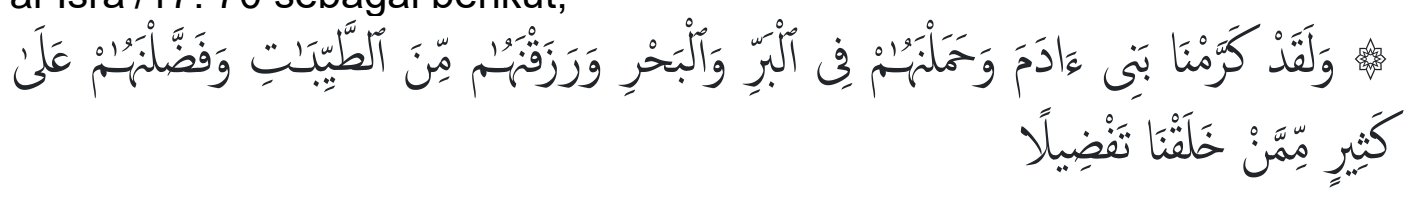

"Dan Sesungguhnya telah Kami muliakan anak-anak Adam, Kami angkut mereka di daratan dan di lauta, Kami beri mereka rezki dari yang baik-baik dan Kami lebihkan mereka dengan kelebihan yang sempurna atas kebanyakan makhluk yang telah Kami ciptakan".

b. Mahluk yang bertanggung jawab.

Manusia diberikan akal untuk memilih dan berusaha, maka manusia akan mempertanggung jawabkan apa yang dilakukannya. Pertanggung jawaban manusia ini tergambar dalam surah al-Ahzab/33: 72

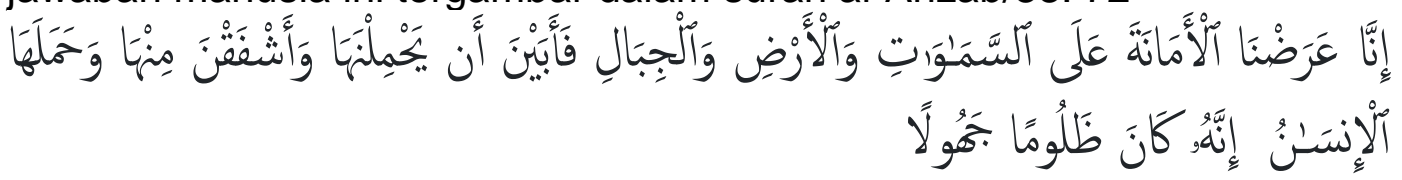

"Sesungguhnya Kami telah mengemukakan amanat kepada langit, bumi dan gunung-gunung, Maka semuanya enggan untuk memikul amanat itu dan mereka khawatir akan mengkhianatinya, dan dipikullah

21 Zakky Mubarak, Menjadi Cendikiawan Muslim (Jakarta: Yayasan Ukhuwah Insaniyah, 2018), h. 22-30 
amanat itu oleh manusia. Sesungguhnya manusia itu Amat zalim dan amat bodoh."

c. Khalifah dan hamba Allah.

Khalifah mengandung makna bahwa Allah menjadikan manusia pemegang kekuasaan untuk menjadikan syari'atNya di bumi. Manusia ditugaskan untuk mengelola alam semesta bagi sesamanya dan mahluk lain. Sebagaimana dalam surah al-An'am/6: 165

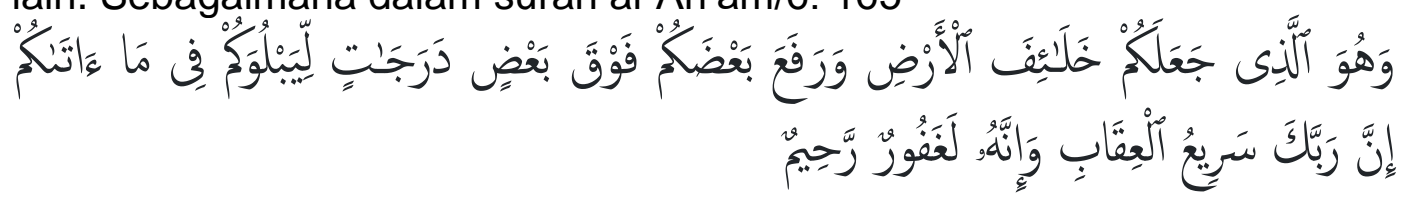

Dan Dialah yang menjadikan kamu penguasa-penguasa di bumi dan Dia meninggikan sebahagian kamu atas sebahagian (yang lain) beberapa derajat, untuk mengujimu tentang apa yang diberikanNya kepadamu. Sesungguhnya Tuhanmu amat cepat siksaanNya dan sesungguhnya Dia Maha Pengampun lagi Maha Penyayang."

d. Mahluk berakhlak.

Akhlak merupakan salah satu cirri yang membedakan manusia dengan mahluk lainnya. Allah memberikan kemampuan kepada manusia untuk dapat membedakan yang hak dan yang bathil, antara yang baik dan yang buruk. Kedudukan dan kemuliaan manusia ditentukan oleh ahlaknya. AlQalam/68: 4

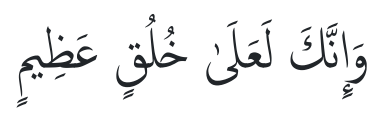

"Dan sesungguhnya kamu benar-benar berbudi pekerti yang agung."

e. Mahluk kontroversial.

Status dan kedudukan manusia dapat menjadi mulia ketika ia menggunakan akalnya, namun sebaliknya menjadi hina apabila tidak menggunakannya. Seperti dijelaskan dalam surah at-Tin/95: 4-6

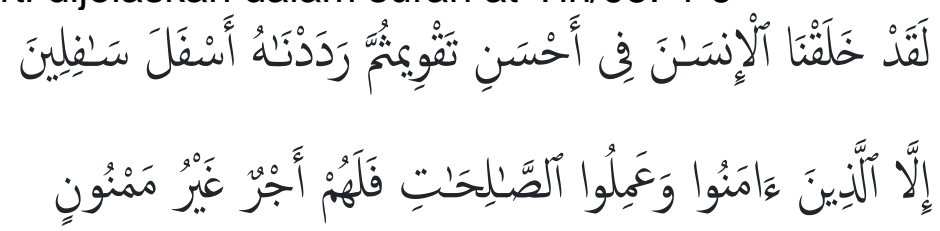

"Sesungguhnya Kami telah menciptakan manusia dalam bentuk yang sebaik-baiknya, kemudian Kami kembalikan Dia ke tempat yang serendah-rendahnya (neraka), kecuali orang-orang yang beriman dan mengerjakan amal saleh; Maka bagi mereka pahala yang tiada putusputusnya."

Dari pemaparan tentang manusia menunjukkan bahawa manusia memiliki 2 sinergi yang sangat luar biasa yaitu jasmani dan rohani. Sinergi 
keduanya terjalin dengan sempurna hingga hampir-hampir keduanya tidak dapat dipisahkan. ${ }^{22}$

\section{Aktualisasimanusia berkualitas berdasarkan surah Ibrahim: 24-25 a. Pengertian manusia berkualitas}

Menurut Kamus Besar Bahasa Indonesia (KBBI), arti kualitas adalah tingkat baik buruknya sesuatu, kadar, derajat atau taraf (kepandaian, kecakapan, dan sebagainya); mutu. Dengan demikian jika dikatakan "berkualitas" maksudnya adalah mempunyai kualitas, bermutu (baik). Manusia terdiri dari dua unsur yaitu jasmani dan rohani, maka manusia berkualitas adalah tingkat kabaikan yang utuh dari kedua unsur tersebut.

Para tokoh psikologi mendefinisikan manusia berkualitas sebagai berikut:

1) Karen Horney (1942), mengatakan bahwa manusia berkualitas adalah orang yang telah mampu menyeimbangkan dorongan-dorongan yang ada dalam dirinya, sehingga terwujudlah tingkah laku yang harmonis. la mampu berhubungan dengan lingkungannya, mampu menciptakan suasana aman dan harmonis. la tidak agresif, tidak mengasingkan diri dari lingkungannya, dan hidupnya tidak pula bergantung pada orang lain.

2) Gordon Allport (1964), manusia berkualitas dipandang sebagai orang yang telah menunjukkan kemampuan untuk memperluas lingkungan hidupnya, menghayati situasi untuk dapat berkomunikasi dengan hangat, menerima dirinya sebagaimana adanya, mempersepsi lingkungan secara realistik, memandang dirinya secara obyektif, serta berpegang pada pandangan hidup secara utuh. Ciri-ciri ini dimiliki oleh manusia yang telah matang (mature).

3) Jourard (1980), manusia berkualitas adalah manusia sehat yang memiliki ciri-ciri sebagai berikut: (a) membuka diri untuk menerima gagasan orang lain; (b) peduli terhadap diri, sesama Manusia dan lingkungannya; (c) kreatif; (d) mampu bekerja yang memberikan hasil (produktif); dan (e) mampu bercinta.

4) Thomas J. Peters dan Robert H.Waterman, manusia berkualitas dilihat dari keberhasilannya menjalankan usaha, adapun ciricirinya sebagai berikut: (a) memiliki kegemaran untuk selalu berbuat sesuatu, daripada banyak bertanya; (b) menampilkan hubungan yang erat dengan para rekannya; (c) bersifat otonom dan memperlihatkan kewiraswastaan; (d) membina kesadaran untuk menampilkan upaya terbaik; (e) memandang penting keuletan dalam menjalankan usaha; (g) menempatkan orang secara proporsional; dan (h) menggunakan prinsip pengawasan yang lentur (longgar tapi ketat). ${ }^{23}$

Dari penyataan dari ketiga tokoh di atas, nampaklah jelas bahwa manusia berkualitas dimulai dari suatu yang baik dari dalam

22 Dedhi Suharto, Qur'anic Quotient: Bagaimana Membangun Kecerdasan Menurut al-Qur'an (Jakarta: PT Prima Print, 2003), h. 9

${ }^{23}$ Mujiono, "Manusia Berkualitas Menurut Al - Qur'an," Hermeunetik Vol. 7, No. 2 (Desember 2013): h. 369

Kuswati | Amtsal Al-Qur'an Dalam Dakwah : Aktualisasi Manusia Berkualitas Berdasarkan Surah Ibrahim : 24-25 
dirinya, dari dalam inilah kemudian muncul prilaku-prilaku yang baik bagi dirinya dan orang lain.

b. Analisis permisalanaktualisasi manusia berkualitas dalam surah Ibrahim: 24-25

Di antara ayat-ayat al-Qur'an yang menggunakan permisalan dalam menyampaikan pesannya adalah surah Ibrahim/14: 25-15. Ayat ini mengajak kita memperhatikan bagaimana menjadi manusia yang berkualitas.

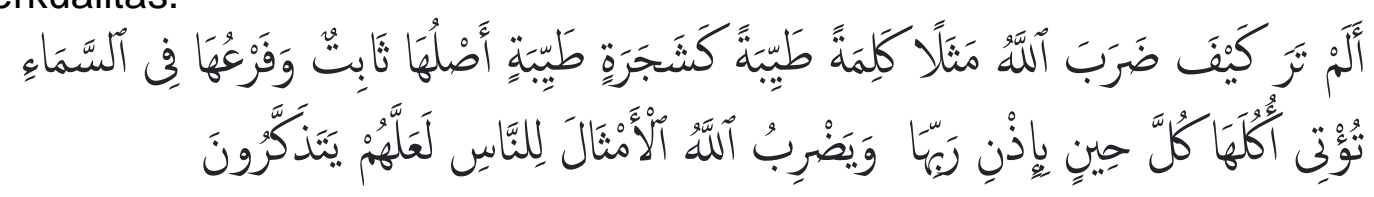

"Tidakkah kamu perhatikan bagaimana Allah telah membuat perumpamaan kalimat yang baik seperti pohon yang baik, akarnya teguh dan cabangnya (menjulang) ke langit. Pohon itu memberikan buahnya pada setiap musim dengan seizin Tuhannya, Allah membuat perumpamaan-perumpamaan itu untuk manusia supaya mereka selalu ingat."

Dalam kitab Jami' al-bayan fi ta'wil al-Qur'an karya imam al-Thobari menjelaskan tentang penafsiran ayat ini sebagai berikut:

$$
\begin{aligned}
& \text { عن ابن عباس، قوله: (كلمة طيبة) ، شهادةُ أن لا إله إلا الله, (كثجرة طيبة) وهو }
\end{aligned}
$$

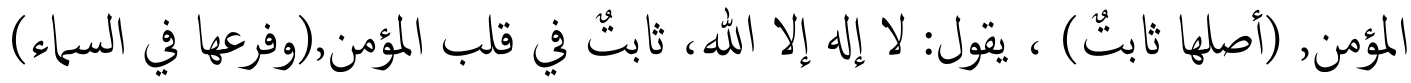

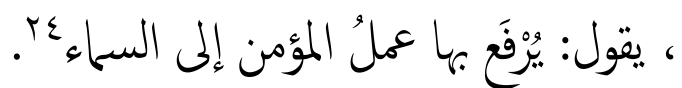

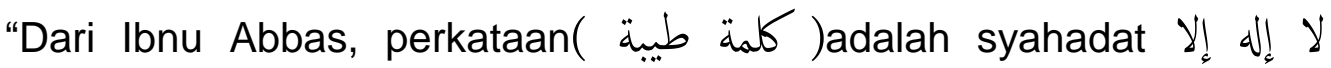
أصلها (كثجرة طيبة(Kalimat) adalah orang mukmin. sedangkan kalimat(الله

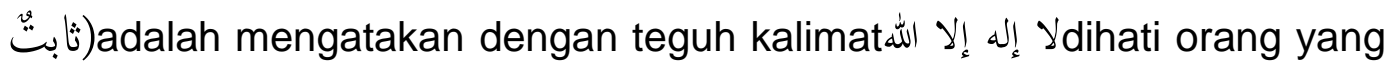
beriman. Kalimat( وفرعها في السماء)yakni amal mukmin yang diangkat ke langit."

$$
\begin{aligned}
& \text { حدثنا عبد الله بن أبي جعفر، عن أبيه، عن الربيع بن أنس: (كلمة طيبة) ، قال: هذا }
\end{aligned}
$$

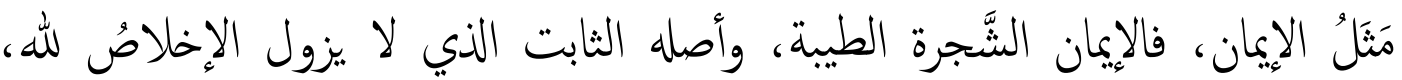

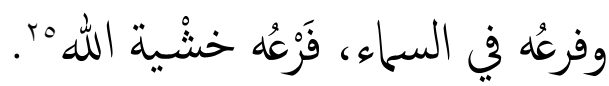

\footnotetext{
${ }^{24}$ Al Thobari, Jami' al-bayan fi ta'wil al-Qur'an (al-muassasah al-Risalah, 2000), h. 567

${ }^{25}$ Ibid,. h. 568
}

Kuswati | Amtsal Al-Qur'an Dalam Dakwah : Aktualisasi Manusia Berkualitas Berdasarkan Surah Ibrahim : 24-25 
'Disampaikan oleh Abdullah bin Ja'far, dari ayahnya, dari Rabi' bin Anas: kalimat(كلمة طية )dia berkata kalimat ini seperti iman, maka iman diumpamakan seperti pohon yang baik, akarnya kokoh senantiasa penuh keikhlasan kepada Allah, cabangnya ke langit, yakni rasa takut kepada Allah".

Mufassir seperti At-Thabari dan Al-Qurthubi menyebut kalimat thayyibah dengan kalimat tauhid, la ilaha illallah. Az-Zamakhshari dalam AlKasysyaf menambahi definisi kalimat thayyibah dengan setiap kalimat yang baik, seperti kalimat tasbih, tahmid, takbir, istighfar, dan semacamnya.Sementara itu, Ibnu Asyur dalam At-Tahrir wa AtTanwir mengartikan thayyibah di sini dengan manfaat. Mengikuti pengertian ini, kalimat thayyibah berarti tidak hanya dibatasi pada kalimatkalimat yang biasa jadi wiridan umat Islam, seperti kalimat tahlil, tahmid, tasbih, takbir, istighfar, hawqalah dan semacamnya, melainkan setiap kalimat yang membawa manfaat, baik untuk diri sendiri maupun orang lain. ${ }^{26}$

Sedangkan, dilihat dari jenis permisalan yang digunakan pada surah Ibrahim tersebut, tegolong amtsal musharrahah karena di dalamnya terdapat lafadz matsal atau sesuatu yang menunjukkan tasybih.Allah memulai ayat ini dengan bentuk pertanyaan dengan menggunakan huruf istifham yaitu hamzah. Di antara para ahli berpendapat bahwa istifham yang terdapat dalam al-Qur'an memberikan pengertian bahwa mukhatab (lawan bicara) sesungguhnya mengetahui apa yang ditetapkan dan apa yang dinafikan. Dengan pertanyaan itu Allah mengingatkan mahlukNya perihal apa yang mereka ketahui. ${ }^{27}$

Ketika kita membaca ayat ini, Allah mengajak manusia untuk melihat perumpamaan pohon yang baik dan bagaiman ciri-ciri pohon tersebut.Allah mempertegas di akhir ayat 25 betapa pentingnya pesan yangterdapat dalam perumpamaan tersebut. Mengenai penafsiran pohon apa sebenarnya yang diumpakan dalam ayat tersebut,lbnu Katsir dalam tafsirnya Tafsir al-Qur'an al-'Adzim atau Tafsir Ibnu Katsimemaparkan panjang lebar tentang pohon apa yang dimaksud melalui jalur periwayatan.

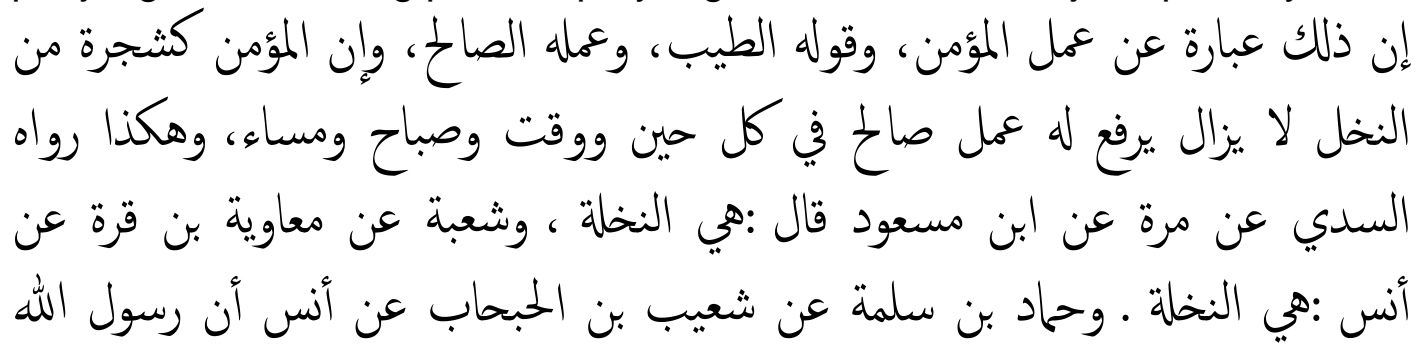

\footnotetext{
26 Tafsir Tematik, diakses pada 5 Juli 2021 dari https://tafsiralquran.id

27 Muhammad Chirzin, al-Qur'an dan Ulumul Qur'an (Yogyakarta: PT. Dana Bhakti Prima Yasa, 1998), h. 181182
}

Kuswati | Amtsal Al-Qur'an Dalam Dakwah : Aktualisasi Manusia Berkualitas Berdasarkan Surah Ibrahim : 24-25 


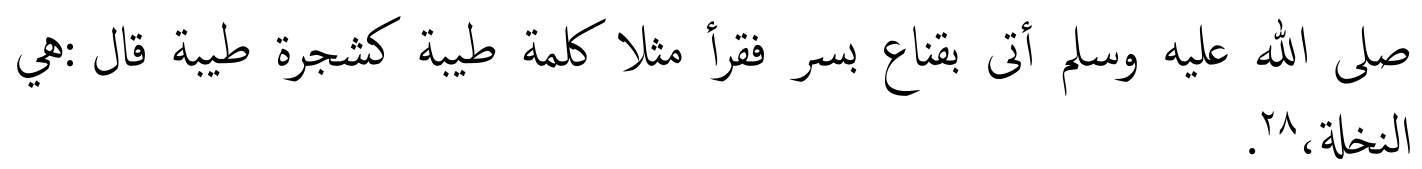

"Sesungguhnya hal tersebut adalah perumpamaan perbuatan seorang mukmin, perkataannya baik, perilakunya baik. Dan sesungguhnya seorang mukmin seperti pohon kurma di mana orang tersebut mengangkat (melakukan) perbuatan sholeh di setiap waktu, pagi maupun sore. Dan inilah yang diriwayatkan oleh Suddi dari Murrah dari Ibnu Mas'ud berkata: yaitu pohon kurma. Dan Su'bah dari Mu'awiyah bin Qurrah dari Anas: yaitu pohon kurma. Dan Hamad bin Salamah dai Su'aib bin Habhab dari Anas bahwa Rasulullah saw datang dengan membawa wadah berisi kurmakemudian membaca permisalan kalimat thoyyibah adalah seperti pohon yang baik, dia berkata: yaitu pohon kurma.

Maka, aktualisasi permisalan pada surah lbrahim/14: 24-25 adalah gambaran manusia yang baik atau manusia yang berkualitas.Karena manusia terdiri dari kesatuan dua unsur yang saling bersinergi yaitu jasmani dan rohani sebagaimana yang dipaparkan pada pembahasan sebelumnya, maka manusia yang berkualitas adalah manusia yang memiliki akidah yang baik dan amal sholeh yang banyak. Dengan akidah yang baik dan kokoh,manusia akan mampu melaksanakan perintahNya dalam konteks syari'at Islam serta memiliki kualitas interaksi dan komunikasi yang baik dengan sesam dan lingkungannya.Gambaran cabang pohon yang menjulang ke langit adalah amal salehnya terusmenerus bertambah dan berkualitas setiap waktu sepanjang hidupnya. Seorang mukmin harus mendedikasikan hidupnya hanya untuk kebaikan.

Jika kita hubungkan dengan ruang lingkup agama Islam atau yang dikenal dengan Hadis Jlbril, ada3 hal yang tidak dapat dipisahkan sebagai seorang mukmin, yakni akidah, syari'at dan ahlak. Maka pemahaman meningkatkan kualitas manusia adalah membangun aktualisasi ketiga pondasi tersebut agar senantiasa kuat. Dan ketiga pondasi ini lah yang merupakan materi yang harus selalu diperkuat dalam dakwah Islamiyyah, sehingga tujuan mengajak manusia untuk baik dalam hablum minallah dan hablum minnasnya tercapai.

\section{KESIMPULAN}

Amtsal al-Qur'an adalah salah satu gaya bahasa dengan bentuk perumpamaan di dalam al-Qur'an. Bentuk ini menjadi menarik karena menghadirkan sesuatu yang abstrak menjadi bentuk nyata, dengan cara menganalogikan benda atau keadaan yang memiliki keserupaan. Bentuk seperti bagian dari retorika dakwah, sehingga ini juga dapat digunakan seorang da'i dalam berdakwah agar pesan dakwah dapat dimengerti dengan cepat dan menyentuh hati. Selain itu, tujuan dari bentuk amtsal adalah memberikan

\footnotetext{
${ }^{28}$ Ibnu Katsir, Tafsir al-Qur’an al-'Adzim (Beirut: Dar al-Kutub al-'Alamiyyah, 1419 H), h. 422
}

\section{Kuswati | Amtsal Al-Qur'an Dalam Dakwah : Aktualisasi Manusia Berkualitas Berdasarkan Surah Ibrahim : 24-25}


penekanan kepada mad'u tentang suatu yang penting dan menjadi prinsip hidup dari apa yang dipermisalkan.

Surah Ibrahim/14: 24-25 termasuk bentuk Amtsal Musarrahahyang di dalamnya terdapat lafadz matsal atau sesuatu yang menunjukkan tasybih. Allah memisalkan kalimat yang baik adalah seperti pohon yang kuat akarnya, cabangnya menjulang ke langit dan menghasilkan buah setiap waktu. Perumpamaan ini yang menggambarkan manusia berkualitas, di mana ia memiliki akidah yang kuat yakni akidah yang bersih atau tidak menyimpang. Selalu melakukan kebaikan yang bermanfaat bagi dirinya dan orang lain, serta perbuatan baik itu senantiasa dia lakukan sepanjang hidupnya. Jika kita hubungkan dengan ruang lingkup ajaran Islam maka aktualisasi manusia yang berkualitas adalah manusia yang teguh akidahnya, istiqomah menjalankan syariatNya dan menghiasi dirinya dengan akhlak yang baik. Dan Allah memberikan pesan yang kuat di akhir ayat 25 berkenaan dengan perumpamaan tersebut: "Dan Allah membuat perumpamaan itu untuk manusia agar mereka selalu ingat."

\section{DAFTAR PUSTAKA}

Abdullah, Muhammad Qadaruddin. Pengantar IImu Dakwah. Jakarta: CV. Qiara Media, 2019.

Abidin, Djamalul. Komunikasi dan Bahasa Dakwah. Jakarta: Gema Insani Press, 1996.

Akip, Muhamad. "Sumber Daya Manusia yang Berkualitas Dalam al-Qur'an." elGhiroh Vol. XVII, No. 02 (September2019)

Chirzin, Muhammad. al-Qur'an dan Ulumul Qur'an. Yogyakarta: PT. Dana Bhakti Prima Yasa, 1998.

Ghazali. Keajaiban Hati. Penerjemah Mansyur al-Katiri. Jakarta: Khtulistiwa Press, 2017.

Hasan, Mohammad. Metodologi Pengembangan IImu dakwah. Surabaya: Pena Salsabila, 2013.

Hermawan, Agus. Retorika Dakwah. Kudus: al-Nur, 2018.

Katsir, Ibnu. Tafsir al-Qur'an al-'Adzim. Beirut: Dar al-Kutub al-'Alamiyyah, $1419 \mathrm{H}$.

Madkhali, Rabi'nin Hadi. Manhaj Dakwah Para Nabi. Penerjemah Abu Fahmi. Jakarta: Gema Insani Press, 1992.

Mubarak, Zakky. Menjadi Cendikiawan Muslim. Jakarta: Yayasan Ukhuwah Insaniyah, 2018.

Mujiono. "Manusia Berkualitas Menurut Al - Qur'an." Hermeunetik Vol. 7, No. 2 (Desember 2013): h. 369

Nuryadien, Mahbub. "Metode Amtsal: Metode al-Qur'an Membangun Karakter." Jurnal al-Tarbawi al-haditsah, Vol.I no.1 issn 2407-6905.

Kuswati | Amtsal Al-Qur'an Dalam Dakwah : Aktualisasi Manusia Berkualitas Berdasarkan Surah Ibrahim : 24-25 
Qattan, Manna' Khalil. Studi IImu-ilmu al-Qur'an, Penerjemah Mudzakir AS. Jakarta: PT Pustaka Lentera Antar Nusa, 2006.

Sada, Heru Juabdin. "Manusia Dalam Perspektif Agama Islam." Al-Tadzkiyyah: Jurnal Pendidikan Islam, Volume 7, 2016.

Shihab, Quraish. Wawasan Al-Qur'an. Bandung: PT Mlzan Pustaka, 2007.

Suharto, Dedhi. Qur'anic Quotient: Bagaimana Membangun Kecerdasan Menurut alQur'an. Jakarta: PT Prima Print, 2003.

Suyuthi. al-Itqon fi ulum al-Qur'an. Cairo: al-Dar al-'alamiyyah, 2016.

Thobari. Jami' al-bayan fi ta'wil al-Qur'an. al-muassasah al-Risalah, 2000.

Wardani, Yaniah. "Pemakaian Pribahasa dan Kata Mutiara dalam Retorika Dakwah Para Da'i di Indonesia: Kajian Stalistika dalam Sastra Arab-Indonesia", Buletin al-Turas Vol. XXIV, No.2, 2018. 